\title{
ІНФОРМАЦІЙНІ ТЕХНОЛОГІЇ В ОЦІНЦІ ЕФЕКТИВНОСТІ ЗАСТОСУВАННЯ ПРЕІМПЛАНТАЦІЙНОЇ ДІАГНОСТИКИ В ПРАКТИЦІ ДОПОМІЖНИХ РЕПРОДУКТИВНИХ ТЕХНОЛОГІЙ
}

\author{
Клініка проблем планування сім'ї МОЗ України
}

\section{С.В. Денисенко}

В практиці молекулярно-цитогенетичного аналізу хромосомних аномалій все більшого значення набуває використання засобів інформаційних технологій, зокрема, на преімплантаційному рівні. Сучасні можливості преімлантаційної діагностики забезпечуються флюоресцентною in situ гібридизацією та порівняльною геномною гібридизацією. Інтерпретація результатів аналізу наявності/відсутності фрлюоресцентних сигналів у ядрах базується на використанні системи Applied Cytovision.

У статті представлено аналіз результатів преімплантаційної діагностики ембріонів, отриманих у ході циклу допоміжних репродуктивних технологій для родини зі збалансованою транслокацією, та оцінка ефективності інформаційних технологій у практиці молекулярно-цитогенетичного аналізу.

Ключові слова: інформаційні технології в преімплантаційній діагностиці, бластомер, FISH-метод.

\section{ИНФОРМАЦИОННЫЕ ТЕХНОЛОГИИ В ОЦЕНКЕ ЭФФЕКТИВНОСТИ ПРИМЕНЕНИЯ ПРЕИМПЛАНТАЦИОННОЙ ДИАГНОСТИКИ В ПРАКТИКЕ ВСПОМОГАТЕЛЬНЫХ РЕПРОДУКТИВНЫХ ТЕХНОЛОГИЙ}

С. В. Денисенко

\author{
Клиника проблем планирования семьи МЗ Украины
}

\begin{abstract}
В практике молекулярно-цитогенетического анализа хромосомных аномалий все большее значение приобретает использование средств информационных технологий, в частности, на преимплантационном уровне. Современные возможности преимплантационной диагностики обеспечиваются флюоресцентной in situ гибридизацией и сравнительной геномной гибридизацией. Интерпретация результатов наличия/отсутствия фрлюоресцентных сигналов в ядрах основывается на использовании системы Applied Cytovision.

В статье представлены анализ результатов преимплантационной диагностики эмбрионов, полученных в ходе цикла вспомогательных репродуктивных технологий для семьи со сбалансированной трансолкацией, и оценку эффективности информационных технологий в практике молекулярно-цитогенетического анализа.
\end{abstract}

Ключевые слова: информационные технологии в преимплантационной диагностике, бластомер, FISH-метод.

\section{INFORMATION TECHNOLOGIES IN THE ASSESSMENT OF THE PREIMPLANTATION GENETIC DIAGNOSIS EFFICIENCY IN THE FIELD OF ASSISTED REPRODUCTIVE TECHNOLOGIES}

\section{S. V. Denysenko}

The Clinic of Human Reproduction Problems of MPH of Ukraine

\begin{abstract}
Application of the information technologies is becoming increasingly important in the practice of molecular and cytogenetic analysis of chromosomal abnormalities in particular on the preimplantation level. Capacity of preimplantation diagnosis is based on fluorescent in situ hybridization (FISH) and comparative genomic hybridization (CGH). Interpretation of FISH/CGH results is performed with the help of Applied Cytovision System.

In the present article we analyze results of the preimplantation diagnosis of embryos, obtained in the IVF program in the family with a balanced translocation. We also evaluate efficacy of the information technologies molecular and cytogenetic analysis.
\end{abstract}

Key words: infor mation technologies in preimplantation diagnosis, blastomere, FISH. 
Вступ. Інформаційні технології посідають чільне місце при отриманні та інтерпретації даних у різних сферах медицини. Однією зі сфер впровадження інформаційних технологій $€$ комп'ютеризоване оброблення даних при проведенні цитогенетичного та молекулярно-цитогенетичного аналізу хромосом. Нещодавно у розпорядженні цитогенетичних лабораторій для аналізу сегментів диференційно забарвлених хромосом були винятково фотовідбитки метафаз або прометафаз. Аналогічною була ситуація і з використанням молекулярно-цитогенетичних методів, зокрема, гібридизації in situ радіоактивно міченими зондами.

Впровадження в практику флюоресцентної гібридизації (FISH) одночасно з розробкою комп'ютеризованої системи оброблення зображення дозволили значно просунутись вперед у діагностиці хромосомних і геномних мутацій на преімплантаційному, пренатальному та постнатальному рівнях. Удосконалення молекулярно-цитогенетичних методів відбувалось i за рахунок впровадження високоочищених ДНКзондів, що в залежності від завдання, поділяються на центромерні, теломерні, локус-специфічні та такі, що забарвлюють усю хромосому (WCH - whole chromosome hybridization).

Нами розглядаються переваги використання системи CYTOVISION в інтерпретації результатів преімплантаційної діагностики збалансованого/незбалансованого каріотипу ембріонів, отриманих у результаті лікувальної програми екстракорпорального запліднення (ЕКЗ) з ICSI для подружньої пари, чоловік в якій був носієм структурної перебудови двох аутосом. Система включає в себе спеціалізоване програмне забезпечення, телекамеру, мікроскоп 3 набором відповідних фільтрів.

Матеріали та методи дослідження. Аналіз результатів FISH розглянемо на прикладі типового звернення у Клініку проблем планування сім'ї в зв'язку з непліддям Чоловікові 27 років, сперміологічний аналіз показав тератозооспермію. Каріотип: 46,XY,t(9; 16)(q22;q12). Дружині 25 років, каріотип в нормі $(46, \mathrm{XX})$. Цитогенетичний аналіз подружньої пари проводився за загальноприйнятим методом [1].

Проведення лікувального циклу суперовуляції в рамках програми екстракорпорального запліднення з ICSI дозволило отримати одинадцять ембріонів. Біопсія одного бластомера ембріонів на восьмиклітинній стадії поділу проводилась на 3 -й день після пункції зрілих ооцитів. Біопсію бластомерів проводили за допомогою лазерної системи MTG згідно з методом, модифікованим в ембріологічній лабораторії Клініки проблем планування сім'ї. Фіксація отриманих бластомерів здійснювалась за ме- тодом Дозорцева Д. І. [2]. Гібридизацію in situ проводили загальноприйнятим методом з модифікаціями, запропонованими Хардарсоном із співавт., і розробленими в лабораторії цитогенетики Клініки проблем планування сім'ї [3]. Флюоресцентну гібридизацію in situ бластомерів проводили із застосуванням теломерних і центромерних ДНК-зондів (Vysis, Abbott Laboratories, IL USA).

Результати молекулярної гібридизації оцінювали, визначаючи наявність/відсутність сигналів і їх кількість у клітинах. Були використані також контрольні препарати для оцінки наявності/відсутності сигналу та характеру їх розташування в клітині.

Аналіз сигналів проводили за допомогою комп'ютерної програми "Cytovision system" (Applied Imaging, UK) та з використанням мікроскопу "Olympus BX60" при збільшенні х1000, укомплектованого лампою HBO x 100, телекамерою та набором фільтрів DAPI/ Rhodamine/FITC.

Результати й обговорення. Преімплантаційна діагностика представляс собою інвазивний метод оцінки ембріонів, який використовують для виявлення анеуплоїдії хромосом, структурних перебудов хромосом, визначення статі, діагностики моногенної патології [4-8]. Вперше метод був успішно застосований у 1989 році для визначення статі ембріона при Х-зчепленій патології [9].

Показаннями для проведення преімплантаційної діагностики є такі фактори: вік матері понад 35 років, наявність структурної хромосомної перебудови у одного з батьків, відсутність результату після проведення кількох циклів допоміжних репродуктивних технологій (ДРТ) в анамнезі, звичне невиношування, наявність X-зчепленої патології в анамнезі, соціальні фактори $[4,5,10,11]$.

Використання ПГД набуло особливого значення в зв'язку з удосконаленням самого методу гібридизації, наявністю широкого вибору комерційних ДНК-зондів та впровадженням комп'ютерної системи візуалізації сигналу. Останній фактор набув особливого значення в преімплантаційній діагностиці, бо дослідник має у своєму розпорядженні для аналізу тільки одну клітину. Проведення ПГД включає в себе дотримання поетапного аналізу: на першому етапі здійснюються визначення наявності/відсутності сигналу в ядрах контрольного препарату, аналіз розміщення сигналів в ядрах контрольного препарату; на другому етапі - аналіз сигналу безпосередньо в ядрах бластомерів. В окремих випадках робота включає додатковий етап - регібридизацію (гібридизація іншими ДНК-зондами).

Інформативність методу висока, проте в деяких випадках аналіз ускладнюється в зв'язку з сумнів- 
ною інтерпретацією результату. До них відносять: слабкий сигнал, його відсутність, поєднання двох сигналів в один, близьке розташування сигналів в ядрі

Якщо у випадку відсутності сигналу необхідно проводити регібридизацію, то при нечіткій візуалізації, слабкому сигналі в нагоді стає комп'ютеризована система. За іiї допомогою можна уточнити результат, отримати чітку картину на всіх зображеннях, фіксованих різними фільтрами, які, накладаючись, дають кольорове відображення наявності/відсутності сигналу в клітині.

Алгоритм аналізу результатів FISH включав послідовність подальших дій. Аналіз сигналів проводився в інтерфазних ядрах контрольних препаратів, отриманих з лімфоцитів периферійної крові носія збалансованої транслокації та його дружини (3 нормальним каріотипом). Оцінювалась наявність/ відсутність сигналів в ядрі та їх кількість. Гібридизаційні сигнали на теломерні ділянки хромосом 9 i 16 спостерігались у 92 \% інтерфазних ядер і 95 \% метафаз, сигнал на центромерний район хромосоми 9 був візуалізований у 96 \% інтерфазних клітин.

\section{Лiтература}

1. Зерова-Любимова Т. Е. Цитогенетичні методи дослідження хромосом людини : методичні рекомендації / Т. Е. Зерова-Любимова, Н. Г. Горовенко. - К. : КМАПО ім. П. Л. Шупика, 2003. - 25 с.

2. Dozortsev D. I. An improved fixation technique for fluorescence in situ hybridization for preimplantation genetic diagnosis / D. I. Dozortsev, K. T. McGinnis // Feritil. Steril. 2001. - P. 186-188.

3. A morphological and chromosomal study of blastocysts developing from morphologically suboptimal human pre-embryos compared with control blastocysts / T. Hardarson, G. Caisander, A. Sjogren [et al/]//Hum. Reprod. -2003 - P. 399-407

4. ESHRE PGD consortium best practice guidelines for organization of a PGD centre for PGD/preimplantation genetic screening / Harton G., Braude P., Lashwood A. [et al.] //Hum. Reprod. - 2011. - P. 14-24.

5. ESHRE PGD Consortium/Embryology Special Interest Group - best practice guidelines for polar body and embryo biopsy for preimplantation genetic diagnosis /screening (PGD/PGS) /
Наступним етапом було проведення FISH на бластомерах, отриманих від одинадцяти ембріонів. Каріотип трьох ембріонів був збалансований. Каріотип семи ембріонів був незбалансований. Результати FISH останнього ембріона були неоднозначними. Мікроскопія бластомера візуалізувала чотири сигнали на теломерні ділянки та один сигнал на центромерну ділянку хромосоми 9 значно більшого розміру. Послідовний аналіз комп'ютерних зображень дозволив визначитись у кількості сигналів та розмежувати їх. Бластомер виявився від ембріона із збалансованим каріотипом, хромосоми 9 були розташовані поблизу, сигнали на центромерні ділянки зливались в один, більшого розміру. Отже, тільки за допомогою комп'ютеризованої системи діагностика ембріонів досягла $100 \%$.

Висновки. Представлені результати дослідження доводять ефективність інформаційних технологій у практиці молекулярно-цитогенетичного аналізу. Продемонстровані переваги комп'ютеризованої системи діагностики анеуплоїдії, а також необхідність обов'язкового використання контрольних препаратів.

G. L. Harton, M. C. Magli, K. Lundin [et al/]//Hum. Reprod. 2011. - P. 41-46.

6. Outcome of preimplantation genetic diagnosis of translocations / S. Munne, M. Sandalinas, T. Escudero [et al.] //Fertil. Steril. -2000. - P. 1209-1218.

7. The importance of aneuploidy screening in reciprocal translocation carriers / A. Pujol, J. Benet, C. Staessen [et al.] // Reproduction. - 2006. - P. 1025-1035.

8. ESHRE PGD Consortium data collection VI: cycles from January to December 2003 with pregnancy follow-up to October 2004 / K. D. Sermon, A. Michiels, G. Harton [et al.] //Hum. Reprod. - 2007. - P. 323-336.

10. Preimplantation genetic diagnosis - an overview / C. M. Ogilvie, P. R. Braude, P. N. Scriven // J. Histochemistry and Cytochemistry - 2005. - P. 255-260.

11. ESHRE PGD Consortium data collection VI: cycles from January to December 2003 with pregnancy follow-up to October 2004 / K. D. Sermon, A. Michiels, G. Harton [et al.] //Hum. Reprod. - 2007. - P. 323-336. 